\title{
Perkembangan dan Pemilihan Karier Menurut Ginzberg dan Implikasinya terhadap Bimbingan dan Konseling
}

\author{
Juliana Batubara $^{1 *}$ \\ ${ }^{l}$ IAIN Imam Bonjol Padang
}

\begin{abstract}
The concept of career development and selection by Ginzberg grouped into fourt elements: process, irreversibilitas, compromise and optimization. As for the career selection process occurs through three periods, namely the period starting fantasy childhood up to 11 years. Tentative period (early adolescence) at the age of 11 to 17 years, which consists of several stages, interests, capacities, values and transitions. Realistic period (mid-teens) at the age of 17 years to early adulthood, approximately 24 years old. This period consists of several stages, namely the exploration phase, and the phase crystallization and specification stage. The power of this theory is that an individual can gradually make the choice to get a career position. The weakness lies in the individual's relationship to the phasepassed.
\end{abstract}

Keyword:Developmental and career selection by Ginzberg

Copyright (C) 2013 IICE - Multikarya Kons - All Rights Reserved

Indonesian Institute for Counseling and Education (IICE) Multikarya Kons

\section{PENDAHULUAN}

Salah satu tujuan perkembangan manusia adalah memilih hidup yang memuaskan dan produktif. Pemilihan karier merupakan salah satu cara untuk mendapatkan kehidupan tersebut. Secara historis pemilihan karier berasal dari bimbingan vokasional yaitu suatu proses dalam membantu klien untuk memilih, mempersiapkan dan memperoleh keberhasilan dalam suatu pekerjaan tertentu. Proses ini dipusatkan dalam konseling dengan mempertimbangkan data klien dan kemungkinan-ke-mungkinan pekerjaan yang ada, agar klien menemukan tujuan karier. Karier sekurang-kurangnya memiliki tiga pilar, yaitu studi atau pendidikan, pekerjaan, dan kehidupan berkeluarga. Ketiga pilar tersebut menjadi bingkai karier seseorang karena alasan-alasan sebagai berikut.

Pertama, manusia menghabiskan sepertiga sampai setengah dari usianya dalam pekerjaan atau aktivitas yang berhubungan dengan pekerjaan. Pekerjaan tidak hanya menentukan pendapatan dan standar hidup, melainkan juga status sosial dan perkembangan kehidupan pribadi baik sebagai pekerja atau sebagai anggota keluarga (suami atau istri yang berkewajiban menjamin kehidupan keluarga), dalam lingkup kehidupan tertentu dan dalam peristiwa kehidupan tertentu.

\footnotetext{
*Telp dan/atau Alamat Email Koresponden : 'Email: batubara.juliana@yahoo.co.id
} 
Jurnal Konseling dan Pendidikan

Kedua, keberhasilan seseorang dalam pekerjaan akan menunjang keberhasilannya dalam memasuki peristiwa kehidupan lainya, dalam lingkup kehidupan yang berbeda dengan peranan hidup yang lain pula, serta membawa kebahagiaan bagi kehidupan pribadi. Sebaliknya ke-gagalan dalam pekerjaan akan meng-hambat kemajuan dalam peristiwa hidup lainnya dan menghambat per-kembangan kepribadian individu.

Ketiga, sebagai persiapan untuk memasuki pekerjaan dan peristiwa hidup lainnya, dalam lingkup kehidupan apapun yang dimasuki, serta peranan apapun yang harus dijalaninya, individu perlu mempersiapkan dirinya melalui pendidikan, termasuk di dalamnya pendidikan formal di sekolah.

Dalam realita kehidupan yang semakin rumit, individu-individu dihadapkan pada persiapan dan pengembangan karier yang semakin kompetitif. Dalam dinamika pengembangan karier individu dihadapkan pada berbagai tantangan sekaligus peluang baru yang menuntutnya untuk merespon secara cerdas. .

Dengan demikian konsep bimbingan karier mengandung arti yang lebih luas dari bimbingan jabatan. Berbagai pandangan tentang per-kembangan karier yang dikenal dengan "teori-teori perkembagan karier" bertujuan untuk mendeskripsikan jalur perkembangan jabatan dan berusaha menjelaskan kaitan antara berbagai faktor yang mempengaruhi per-kembangan itu. Masing-masing teori memiliki kekhasan tersendiri dalam memandang perkembangan karier tersebut. Makalah ini akan membahas mengenai salah satu toeri mengenai perkembangan karier yaitu Ginzberg.

\section{Pokok Teori}

Hal yang mendasar bagi Ginzberg dalam membangun teorinya adalah pendekatan psikologis atas tugastugas perkembangan yang dilalui manusia. Konsep perkembangan dan pemilihan karier oleh Ginzberg dikelompokkan dalam empat unsur yaitu:

1. Proses (bahwa pilihan pekerjaan itu merupakan suatu proses yang berlangsung secara terus-menerus).

2. Irreversibilitas (bahwa pilihan pekerjaan itu tidak bisa diubah atau dibalik. Adanya pembatasan pilihan pekerjaan itu bersifat menentukan. Jadi umur akan mempengaruhi karier seseorang dan kesediaan kesempatan bisa saja menyebabkan orang berubah dalam pilihan pekerjaannya).

3. Kompromi (bahwa pilihan pekerjaan itu merupakan kompromi antara faktor-faktor yang lain yaitu minat, kemampuan, dan nilai. Dalam unsur kompromi ini seseorang mulai mencari kesempurnaannya melalui perkembangan sehingga muncullah konsep optimis).

4. Optimisasi yang merupakan penyempurnaan teori (individu yang mencari kecocokan kerja, baik antara minat yang terus mengalami perubahan, tujuannya, dan keadaan yang terus berubah).

\section{Proses Pemilihan Karier}

Menurut Ginzberg proses pemilihan karier tidak hanya terjadi sekali saja melainkan mengalami suatu proses perkembangan yang meliputi jangka waktu. Pada umumnya mencakup kurun waktu selama enam hingga sepuluh tahun, yang dimulai dari sekitar usia 11 tahun dan berakhir sesudah usia 17 tahun atau awal masa dewasa. Terdapat tiga periode atau tahapan dalam proses pemilihan pekerjaan yaitu periode fantasi, tentatif, dan realistik dengan karakteristik sebagai berikut:

\begin{tabular}{|l|l|l|}
\hline \multicolumn{1}{|c|}{ Periode } & \multicolumn{1}{|c|}{ Usia } & \multicolumn{1}{|c|}{ Karakteristik } \\
\hline Fantasi & $\begin{array}{l}\text { Masa kanak-kanak (sebelum } \\
\text { usia 11 tahun) }\end{array}$ & $\begin{array}{l}\text { Pada tahap awal ini orientasi pekerjaan tampak dalam } \\
\text { permainan yang murni. Menjelang akhir tahap ini } \\
\text { permainan menjadi orientasi pekerjaan. }\end{array}$ \\
\hline Tentatif & $\begin{array}{l}\text { Awal masa remaja (usia 11 } \\
-17 \text { tahun) }\end{array}$ & $\begin{array}{l}\text { Proses transisi yang ditandai oleh pengenalan secara } \\
\text { berangsur-angsur persyaratan kerja. Pengenalan } \\
\text { terhadap perspektif bakat, minat, kemampuan, } \\
\text { kecakapan, imbalan kerja, nilai danwaktu }\end{array}$ \\
\hline Realistik & $\begin{array}{l}\text { Pertengahan masa remaja } \\
\text { (usia 17 tahun sampai awal } \\
\text { masa dewasa) }\end{array}$ & $\begin{array}{l}\text { Pengintegrasian kemampuan dan minat. Kelanjutan } \\
\text { perkembangan nilai-nilai. Spesifikasi pilihan okupasi } \\
\text { dan kristalisasi pola-pola okupasi. }\end{array}$ \\
\hline
\end{tabular}


Jurnal Konseling dan Pendidikan

Sumber: Vernon G.Zunker,Career Counseling: Applied Concepts of life planning

Dari tabel di atas masing-masing periode dapat diuraikan sebagai berikut:

1. Masa Fantasi

Masa ini berlangsung pada individu dari masa kanak-kanak sampai kira-kira 10 tahun atau 11 tahun (masa sekolah dasar). Pada masa ini, proses pemilihan pekerjaan masih bersifat sembarangan atau asal pilih, tanpa didasarkan pada pertimbangan yang matang (rasional dan objektif) mengenai kenyataan yang ada. Pilihan pekerjaan pada masa ini hanya didasari atas kesan yang dapat melahirkan kesenangan semata, dan diperolehnya dari/mengenai orang-orang yang bekerja atau lingkungan kerjanya.

Menurut Winkel (2005) selama periode ini, anak mula-mula hanya bermain saja dan permainan ini dianggap tidak mempunyai kaitan dengan dunia kerja. Oleh karena itu, fase ini tidak diberi banyak perhatian oleh kelompok Ginzberg. Pada akhir fase pertama ini permainan anak mulai menampakkan beberapa indikasi bahwa dia kelak cenderung memilih sejumlah aktivitas tertentu yang mengarah kepada peran sebagai pemegang suatu jabatan.

2. Masa Tentatif

Masa ini berlangsung pada usia lebih kurang 11 tahun sampai 17 tahun atau pada masa anak bersekolah di SLTP dan SLTA. Pada masa ini, pilihan pekerjaan mengalami perkembangan.

Menurut Ginzberg masa ini diklasifikasikan manjadi empat tahap, yaitu:

a. Tahap minat/ Interest (11-12 tahun) yaitu masa dimana individu cenderung melakukan pekerjaan/kegiat-an hanya yang sesuai dengan minat dan kesukaan mereka saja. Pertimbangan karierpun juga didasari atas kesenang-an, ketertarikan atau minat individu terhadap objek karier, dengan tanpa mempertim-bang $\neg \neg$ kan banyak faktor.

b. Tahap kapasitas/Capacity (13-14 tahun), yaitu masa dimana individu mulai melakukan pekerjaan/kegiatan didasarkan pada kemampuan yang dimilikinya sesuai dengan aspirasi tentang pekerjaan. Orientasi pilihan pekerjaan juga pada masa ini berbentuk upaya mencocok-kan kemampuan yang dimiliki dengan minat dan kesukaannya.

c. Tahap nilai/ Value (15-16 tahun), yaitu tahap dimana individu mulai menyadari bahwa terdapat suatu kandungan nilai-nilai tertentu dari suatu jenis pekerjaan, baik kandungan nilai yang bersifat pribadi maupun serangkaian nilai yang bersifat kamasyarakatan. Kesadaran akan serangkaian kandungan nilai ini pula yang membuat individu dapat mendiferensiasikan nilai suatu pekerjaan dengan pekerjaan lainnya. Pada tahap ini mulai terbentuknya persepsi yang lebih jelas tentang gaya okupasional.

d. Tahap transisi/ Transition (16-17 tahun), yaitu keadaan dimana individu akan memadukan orientasiorientasi pilihan yang dimiliki sebelumnya (minat, kapasitas, dan nilai) untuk dapat direalisasikan dalam kehidupannya. Tahap ini dikenal juga dengan tahap pengenalan secara gra $\neg$ dual terhadap persyaratan kerja, penge $\neg$ nalan minat, kemampuan, imbalan kerja, nilai, dan perspektif waktu. Keputusan yang menjadi pilihan itu sudah merupakan bentuk tanggu $\neg$ ng jawab dan konsekuensi pola karier yang dipilih. Dengan kata lain tahap ini individu memperoleh gambaran diri yang lebih utuh dan menyadari segala konsekuensi riil dalam mengambil suatu ketentuan tentang jabatannya kelak.

\section{Masa Realistik}

Masa ini berlangsung pada usia 17-24 tahun atau pada masa perkuliahan atau mulai bekerja. Pada masa ini, okupasi terhadap pekerjaan telah mengalami perkembangan yang lebih realistis. Orientasi minat, kapasitas, dan nilai yang dimiliki individu terhadap pekerjaan akan direfleksikan dan diintegrasikan secara runtut dan terstruktur dalam frame vokasional (kristalisasi pola-pola okupasi) untuk memilih jenis pekerjaan dan atau memilih perguruan tinggi yang sesuai dengan arah tentatif mereka (spesifikasi). Masa ini pun dibedakan menjadi tiga tahap yaitu : 
1. Tahap eksplorasi/ Exploration.

Pada tahap ini individu mempersempit kemungkinan-kemungkinan pilihan karier dengan memberikan penilaian atas pengalaman atau kegiatan yang berhubungan dengan pekerjaan dalam keterkaitannya terhadap tuntutan kerja yang sebenarnya. Penilaian ini pada hakikatnya berfungsi sebagai acuan dan atau syarat untuk bisa memasuki lapangan pekerjaan atau untuk melanjutkan pendidikan ke perguruan tinggi.

2. Tahap kristalisasi/Chrystalization.

Pada tahap ini penilaian yang dilakukan individu terhadap pengalaman atau kegiatan-kegiatan yang berhubungan de $\neg$ ng-an pekerjaan baik yang berhasil ataupun yang gagal akan mengental dalam bentuk pola-pola vokasional yang jelas, sehingga individu memiliki komitmen terhadap karier yang spesifik dan merasa lebih mantap jika memangku jabatan tertentu.

3. Tahap spesifikasi/ Specification.

Tahap ini merupakan tahap pilihan pekerjaan yang spesifik atau khusus. Pada tahap ini, semua segmen dalam ori-entasi karier yang dimulai dari orientasi minat, kapasitas, dan nilai $\neg$, sampai tahap eksplorasi dan kristalisasi telah dijadikan pertimbangan (kompromi) yang matang (determinasi tugastugas perkembangan yang optimal) dalam memilih arah dan tujuan karier dimasa yang akan datang. Dengan kata lain pada tahap ini individu mengambil keputusan tentang jabatan tertentu untuk mencapai karier yang lebih spesifik.

\section{Kekuatan dan Kelemahan Teori Ginzberg}

Menurut pandangan teori ini pilihan karier tidak hanya terjadi sekali saja melainkan mengalami suatu proses perkembangan yang meliputi jangka waktu tertentu. Sehingga pilihan-pilihan yang dibuat awal proses perkembangan vokasional berpengaruh terhadap pilihan selanjutnya, dengan demikian suatu keputusan yang diambil dapat ditinjau kembali. Ginzberg menekankan kembali bahwa pilihan okupasional merupakan proses pembuatan keputusan seumur hidup bagi mereka yang mencari kepuasan dari kerjanya. Ini berarti bahwa mereka harus senantiasa menilai ulang bagaimana mereka dapat meningkatkan kecocokan antara perubahan tujuan kariernya dengan realita dunia kerja.

Kelompok ini berpendapat ada empat variabel penting yang berpengaruh terhadap pilihan karir yaitu faktor realita, proses pendidikan, emosional dan nilai-nilai individu yang dianggap perlu dalam pemilihan karier. Teori ini lebih bersifat deskriptif dari pada eksplanatori, artinya bahwa teori ini tidak memberikan strategi untuk memfasilitasi perkembangan karier ataupun penjelasan tentang proses perkembangannya. Kegunaan utama dari teori ini adalah untuk memberikan satu kerangka baru dalam melakukan studi mengenai perkembangan karier.

Adapun kekuatan teori ini adalah dengan melewati fase seorang individu secara berangsur-angsur dalam jabatan, dan sifatnya yang masih sementara sampai orang dewasa dapat membuat pilihan jabatan untuk mendapatkan kariernya, sedangkan kelemahannya terletak pada keterkaitan individu pada fase yang dilalui.

\section{Implikasi Teori Ginzberg Terhadap Bimbingan dan Konseling}

Adapun implikasi perkembangan dan pemilihan karier menurut Ginzberg bagi Bimbingan dan konseling adalah sebagai berikut:

1. Perkembangan karier merupakan salah satu aspek dari keseluruhan proses perkembangan individu dan pilihan yang berkaitan dengan jabatan dimasa depan. Hal ini berlangsung selaras dengan perkembangan karier. Jika proses perkembangan individu tidak berjalan sebagaimana mestinya maka laju perkembangan karier juga tidak akan berjalan lancar dan banyak pilihan karier akan menunjukkan kekurangan yang berat. Karena itu, bimbingan karier harus direncanakan dan dikelola dengan maksud menunjang perkembangan karier individu, sesuai dengan tahap perkembangan diberbagai jenjang pendidikan disekolah.

2. Pengenalan terhadap minat, kapasitas, yang dimiliki siswa dan perangkat nilai yang dianutnya akan sangat diperlukan oleh guru pembimbing dalam upaya mengembangkan, membina, dan mengarahkan 
siswa pada pola-pola vokasional dan atau pemilihan pendidikan yang tepat dan selaras dengan kondisi dan pilihan karier tersebut

3. Informasi karier atau pekerjaan oleh guru pembimbing akan lebih memungkinkan siswa untuk dapat mengenal berbagai jenis pekerjaan dan pola karier yang dapat mereka pilih setelah menyelesaikan pendidikannya. Layanan seperti ini juga dapat membantu siswa dalam mengenal secara seksama arah minat dan kemampuan (potensi diri). Menurut Munandir (1996:250) informasi yang dapat diberikan berkenaan dengan informasi jenis-jenis pekerjaan dan informasi jenis-jenis pendidikan. Bentuk lain materi layanan informasi karier yang juga dapat diberikan guru pembimbing adalah dengan penyediaan berbagai sumber informasi pekerjaan, jabatan dan karier, penyediaan papan media bimbingan, dan penyediaan sumber-sumber informasi jabatan (Ketut, $1984: 238-239$ )

4. Pilihan jabatan tidak dibuat sekali saja dan tidak definitive dengan sekali memilih saja. Individu membuat suatu rangakain pilihan yang berkesinambungan dan bertahap, dari pilihan yang masih bersifat agak luas dengan memilih bidang jabatan sampai jabatan tertentu dibidang itu. Hal ini bertujuan memberikan gambaran diri yang merupakan garis dasar untuk menyambung dan memadukan semua pilihan yang dibuat. Karena itu, bimbingan karier harus menunjang individu untuk mengenal dirinya sendiri dengan lebih baik. Pemahaman diri ini menjadi benang merah dalam menyusun rencana masa depan dan semua pilihan yang dibuat mendapat maknanya sebagai implementasi konkret dari konsep diri.

\section{KESIMPULAN}

Berdasarkan uraian teori Ginzberg di atas dapat disimpulkan bahwa:

1. Pilihan okupasional tidak terjadi sekali saja melainkan mengalami suatu proses perkembangan, yang pada umumnya mencakup tiga periode atau tahapan.

2. Periode fantasi dimulai sejak masa kanak-kanak hingga 11 tahun.

3. Periode tentative (awal masa remaja) pada usia 11 hingga 17 tahun, yang terdiri dari beberapa tahap yaitu minat, kapasitas, nilai dan transisi.

4. Periode realistic (pertengahan remaja) pada usia 17 tahun hingga awal masa dewasa, kurang lebih 24 tahun. Periode ini terdiri dari beberapa tahap, yaitu tahap eksplorasi, tahap kristalisasi dan dan tahap spesifikasi.

\section{DAFTAR RUJUKAN}

Brown, Duane, ey.al. 1987.Career Choice and Development. San Fransisco, California: Jossey Bass Inc.

Ghani, R. A. 1985.Bimbingan Karir. Bandung : Aksara

Munandir, 1996.Program Bimbingan Karir di Sekolah. Jakarta :Depdikbud, Dikti.

Sukardi, D. K. dkk. 1990.Tes Dalam Konseling Karir (teori tes dan Interpretasi Tes). Surabaya: Usaha Nasional.

Winkel, \&Sri Hastuti, 2005.Bimbingan dan Konseling di Institusi Pendidikan (Edisi Revisi). Yogyakarta: Media Abadi. 